\title{
PENGARUH KEPEMILIKAN INSTITUSIONAL DAN DEWAN KOMISARIS INDEPENDEN TERHADAP KINERJA KEUANGAN DI BURSA EFEK INDONESIA
}

\author{
Shelly Monica ${ }^{1)}$, Aminar Sutra Dewi ${ }^{2)}$ \\ Sekolah Tinggi Ilmu Ekonomi KBP \\ shellymnc18@gmail.com \\ aminarsutradewi@akbpstie.co.id
}

\begin{abstract}
This study aims to find out the influence of institusional ownership, and independent board of commissioners to financial performances on manufacture companies. The study objects is manufacturing company which listed in Indonesian Stock Exchange and the observation period from 2013 to 2017, the sampling technique used is purposive sampling. This study used data of company'sannual financial statement and annual report summary has been obtained from the official website of IDX. This type study isquantitative research. The sample used was companies manufacture in 2013-2017 totaling 53 samples. Data analysis method used in this study is regression analysis in panel data. The result of the study show that institusional ownership has a significant effect on financial performances (ROA). Independent board of commissioners has a significant positive not effect on financial performances (ROA).
\end{abstract}

Keywords: institusional ownership, independent board of commissioners, financial performances (ROA).

\section{PENDAHULUAN}

Isu perusahaan manufaktur di bursa efek Indonesia ekonomi di universitas Indonesia dalam pertumbuhan industri manufaktur menunjak tinggi.Karena, sektor manufaktur sangat berpengaruh terhadap energi baru yang dapat mendorong pertumbuhan ekonomi serta belanja masyarakat pun meningkat. Salah satu perusahaan yang memiliki kinerja keuangan yang baik yaitu perusahaan manufaktur. Sektor industri manufaktur menjadi tulang punggung pertumbuhan nasional. Setelah mengalami kondisi krisis, industri manufaktur selalu tumbuh di bawah produk domestik bruto (PDB). Sehingga Indonesia tidak bisa menjadi negara industri. Justru pertumbuhan sektor jasa nasional yang baik, inilah yang menjadi aneh. Memang industri manufaktur tidak semua sektor jelek pertumbuhannya, ada juga industri manufaktur yang cemerlang. Pertama, sub sektor kosmetik \& barang keperluan rumah tangga, kedua sub sektor keramik, porselen, \& kaca, ketiga sub sektor pakan ternak, ke empat sub sektor otomotif dan komponennya, serta sub farmasi. Mereka tumbuh di atas rata-rata dan selama ini mencerminkan pertumbuhan yang sangat pesat. Namun, hal itu belum bisa membantu pertumbuhan ekonomi nasional secara umum. Sehingga, semua sektor manufaktur harus digenjot terus.

Kinerja keuangan adalah suatu laporan keuangan perusahaan yang menunjukkan keadaan perusahaan dimana akan digunakan untuk bahan pertimbangan bagi perusahaan untuk melakukan tindakan selanjutnya maupun bagi 
masyarakat untuk menilai kelancaran perusahaan tersebut sebelum melakukan tindakan (Dewi, Zusmawati, \& Lova, 2018). Sebagai pengelola perusahaan pihak manajer lebih banyak mengetahui prospek perusahaan dan informasi internal di masa yang akan datang dibandingkan pemilik atau (pemegang saham). Manajer memiliki kewajiban memberi sinyal tentang kondisi perusahaan kepada pemilik perusahaan.

Kinerja keuangan perusahaan itu sendiri diukur dengan menggunakan Return On Asset (ROA) yang merupakan pengukuran aspek akuntansi. Pengukuran akuntansi ROA merupakan pencerminan dari kinerja perusahaan. ROA menunjukkan bahwa kemampuan yang dimiliki perusahaan dengan menggunakan seluruh aset yang dimiliki oleh perusahaan untuk menghasilkan laba setelah pajak (Putra, 2015).

Salah satu laporan keuangan yang mengukur keberhasilan operasi perusahaan untuk suatu periode tertentu adalah laporan laba rugi. Akan tetapi angka laba yang dihasilkan dalam laporan laba rugi seringkali dipengaruhi oleh metode akuntansi yang digunakan. Disclosure laporan keuangan akan memberikan informasi yang berguna bagi pemakai laporan keuangan. Disclosure sebagai salah satu aspek good corporate governance diharapkan dapat menjadi dasar untuk melihat baik tidaknya kinerja perusahaan (Puspitasari \& Ernawati, 2010).

Dalam buku manajemen keuangan karangan Harjito \& Martono (2011) dalam Agency Theory menyimpulkan bahwa, Agency Theory merupakan teori yang berhubungan antara pengelola perusahaan dan pemegang saham. Perusahaan dituntut untuk bertindak yang terbaik untuk memenuhi kepentingan pemegang saham. Namun dalam praktik pada sekarang ini masih sering terjadinya konflik antara kedua belah pihak tersebut yang dinamakan agency problem (Harjito \& Martono, 2011).

\section{Keterkaitan Kepemilikan Institusional Dengan Kinerja Keuangan}

Kepemilikan institusional merupakan kepemilikan saham oleh pihak institusi lain yaitu kepemilikan oleh perusahaan atau lembaga lainnya. Kepemilikan saham oleh pihak-pihak yang terbentuk institusi seperti perusahaan asuransi, bank, perusahaan investasi, dan kepemilikan institusi lain. Kepemilikan institusional merupakan suatu alat yang dapat digunakan untuk mengurangi agency conflict (Putra, 2017). Dalam penelitian diukur dengan menggunakan indikator persentase jumlah saham yang dimiliki institusi dari keseluruhan modal saham beredar.

Kepemilikan institusional memiliki arti penting dalam memonitor manajemen karena dengan adanya kepemilikan oleh institusional akan mendorong peningkatan pengawasan yang lebih optimal. Monitoring tersebut tentunya akan menjamin kemakmuran untuk pemegang saham, pengaruh kepemilikan institusional sebagai agen pengawas ditekan melalui investasi mereka yang cukup besar dalam pasar modal (Susanto \& Pricilia, 2017). Secara teoritis bahwa semakin kuat kontrol terhadap perusahaan maka akan semakin tinggi pula kepemilikan institusional terhadap perusahaan, kinerja perusahaan akan naik apabila pemilik perusahaan bisa mengendalikan perilaku manajemen supaya bertindak sesuai dengan tujuan perusahaan. Berdasarkan uraian tersebut maka dapat dirumuskan hipotesis pertama yaitu :

\section{H1 : Diduga kepemilikan institusional berpengaruh positif dan signifikan terhadap kinerja keuangan}




\section{Keterkaitan Dewan Komisaris Independen Dengan Kinerja Keuangan}

Komisaris independen adalah anggota dewan komisaris yang tidak memiliki hubungan keuangan, kepengurusan, kepemilikan saham dan/atau hubungan keluarga dengan anggota dewan komisaris lainnya, direksi dan atau pemegang saham pengendali atau hubungan lain yang dapat mempengaruhi kemampuannya untuk bertindak independen (Zahra, 2016).

Komisaris independen merupakan posisi terbaik untuk melaksanakan fungsi tersebut agar tercipta perusahaan dengan good corporate governance (Dewi, Sari, \& Abaharis, 2018). Proporsi Dewan Komisaris diukur menggunakan indikator persentase anggota dewan komisaris yang berasal dari eksternal perusahaan dari seluruh ukuran anggota dewan komisaris perusahaan.

Karena semakin besar jumlah dewan komisaris akan semakin sulit, serta mahal dan memakan waktu lama dalam hal baik komunikasi, maupun koordinasi dalam pembuatan keputusan (Putra, 2015). berdasarkan uraian tersebut maka dapat dirumuskan hipotesis pertama yaitu :

\section{H2 : Diduga dewan komisaris independen berpengaruh positif dan signifikan terhadap kinerja keuangan}

\section{METODE PENELITIAN}

Penelitian dilakukan terhadap perusahaan manufaktur yang terdaftar di Bursa Efek Indonesia selama periode 2013 - 2017. Dasar pemilihan obyek penelitian ini adalah tidak adanya kendala dalam pengumpulan data, serta data dapat dikumpulkan dalam waktu yang relatif singkat. Data yang digunakan dalam penelitian merupakan data sekunder yang diperoleh melalui situs resmi Bursa Efek Indonesia (www.idx.co.id). Data kuantitatif diperoleh dari annual report dan annual report summary. Data kuantitatif diambil dari salah satu laporan keuangan perusahaan berupalaporan posisi keuangan.

Adapun jenis penelitian ini adalah penelitian kuantitatif dimana penelitian ini melakukan pengujian terhadap hipotesis terkait dengan hubungan antara beberapa variabel terhadap variabel lainnya dengan memanfaatkan data berupa angka angka yang sudah jadi dan tersedia untuk dilakukan pengujian lebih lanjut. Metode ini sebagai metode ilmiah / scientific karena telah memenuhi kaidah-kaidah ilmiah yaitu konkret / empiris, obyektif, rasional, terukur, dan sistematis (Sugiyono, 2017a)

Teknik pengumpulan data yang digunakan adalah dokumentasi. Sebanyak 147 perusahaan terdaftar pada akhir periode 2017 menjadi populasi dalam penelitian. Sampel diambil dengan menggunakan metodepurposive sampling, yaitu suatu metode penarikan sampel dengan kriteria khusus yang telah ditentukan oleh peneliti.

Kriteria untuk pengambilan sampel pada pengamatan ini yaitu :

1. Perusahaan manufaktur yang terdaftar di bursa efek indonesia diakhir periode observasi pada tahun 2017, yang diperoleh dari ICMD (www.idx.co.id).

2. Perusahaan manufaktur yang terdaftar secara berturut-turut selama periode 2013-2017. 
3. Perusahaan manufaktur yang terdapat informasi laporan keuangan tahunan atau laporan keuangan yang telah di audit mencakup seluruh variabel yang digunakan dalam penelitian.

4. Perusahaan manufaktur dengan data ROA yang bernilai positif.

\section{Tabel 1}

Tabulasi Pengambilan Sampel Menggunakan Purposive Sampling

\begin{tabular}{clc}
\hline No. & \multicolumn{1}{c}{ Kriteria } & Jumlah \\
\hline 1 & $\begin{array}{l}\text { Perusahaan manufaktur yang terdaftar di BEI pada akhir } \\
\text { periode observasi, yaitu Tahun 2017. }\end{array}$ & 147 \\
2 & $\begin{array}{l}\text { Perusahaan manufaktur yang tidak terdaftar secara berturut- } \\
\text { turut selama periode 2013-2017 }\end{array}$ & $(20)$ \\
& $\begin{array}{l}\text { Perusahaan manufaktur yang tidak menyediakan data-data } \\
\text { yang dibutuhkan sesuai dengan variabel dalam penelitian }\end{array}$ & $(30)$ \\
4 & $\begin{array}{l}\text { Perusahaan manufaktur yang tidak memiliki data ROA } \\
\text { bernilai positif. }\end{array}$ & \multicolumn{1}{c}{ Jumlah Sampel } \\
\hline & \multicolumn{1}{c}{ Jumlah Observasi } & $\mathbf{5 3}$ \\
\hline
\end{tabular}

\section{Definisi Operasional Variabel}

Dalam penelitian ini, variabel yang digunakan terdiri dari dua macam, yaitu variabel bebas (independent variables) dan variabel terikat (dependent variables). Yang menjadi variabel bebas dalam penelitian kali ini adalah kepemilikan institusional dan dewan komisaris independen. Sedangkan kinerja keuangan sebagai Y dimana berperan sebagai variabel terikatnya. Definisi operational variabel dapat dilihat pada tabel berikut ini:

Tabel 3.2

Definisi Operasional Variabel

\begin{tabular}{|c|c|c|c|c|}
\hline No & Variabel & Definisi & Measurement (pengukuran) & Sumber \\
\hline \multirow[t]{6}{*}{1} & \multirow{6}{*}{$\begin{array}{l}\text { Kinerja } \\
\text { Keuangan } \\
\text { (Variabel } \\
\text { Y) }\end{array}$} & \multirow{6}{*}{$\begin{array}{lrr}\text { Returnon } & \text { Aset } & \text { (ROA) } \\
\text { merupakan } & \text { ukuran } \\
\text { efektivitas } & \text { perusahaan di } \\
\text { dalam } & \text { menghasilkan } \\
\text { keuntungan } & \text { dengan } \\
\text { memanfaatkan } & \text { aset } \\
\text { perusahaan.. } & \end{array}$} & \multirow{6}{*}{$\mathrm{ROA}=\frac{\text { Laba Setelah } \text { Pajak }}{\text { Total } \text { Asset }} \times 100 \%$} & \multirow{6}{*}{$\begin{array}{l}\text { (Hidayanti \& } \\
\text { Paramita, } \\
\text { 2014) }\end{array}$} \\
\hline & & & & \\
\hline & & & & \\
\hline & & & & \\
\hline & & & & \\
\hline & & & & \\
\hline \multirow[t]{2}{*}{2} & Kepemilika & \multirow{2}{*}{$\begin{array}{l}\text { Kepemilikan institusional } \\
\text { merupakan jumlah } \\
\text { kepemilikan saham yang } \\
\text { dimiliki oleh investor } \\
\text { institusional dibandingkan } \\
\text { dengan jumlah yang beredar. }\end{array}$} & \multirow{2}{*}{$\begin{array}{l}\text { Kepemilikan institusional }= \\
\frac{\text { jumlah saham institusional }}{\text { jumlah saham yang beredar }}\end{array} 100 \%$} & \multirow{2}{*}{$\begin{array}{l}\text { (Hidayanti \& } \\
\text { Paramita, } \\
\text { 2014) }\end{array}$} \\
\hline & $\begin{array}{l}\text { Institusional } \\
\text { (Variabel } \\
\text { X1) }\end{array}$ & & & \\
\hline \multirow[t]{5}{*}{3} & Dewan & Proporsi Dewan Komisaris & \multirow{5}{*}{$\begin{array}{l}\text { Komisaris independen }= \\
\frac{\text { jumlah komisaris independen }}{\text { jumlah keanggotaan dewan komisaris }} \times 100 \%\end{array}$} & \multirow{5}{*}{$\begin{array}{l}\text { (Widyati, } \\
\text { 2013) }\end{array}$} \\
\hline & Komisaris & Independen diukur & & \\
\hline & Independen & menggunakan indikator & & \\
\hline & (Variabel & persentase anggota dewan & & \\
\hline & $\mathrm{X} 2)$ & komisaris yang berasal dari & & \\
\hline
\end{tabular}




luar perusahaan dan dari
seluruh ukuran anggota
dewan
perusahaan.

Teknis Analisis Data

Analisis Statistik Deskriptif

Sugiyono (2017) menyatakan, statistik deskriptif juga dilakukan untuk mencari kuatnya hubungan antara variabel melalui analisis korelasi, melakukan prediksi dengan analisis regresi dan membuat perbandingan dengan membandingkan rata - rata data sampel atau populasi. Jadi secara teknis dapat diketahui bahwa, dalam statistik deskriptif tidak ada uji signifikansi, tidak ada taraf kesalahan, karena peneliti tidak bermaksud membuat generalisasi, sehingga tidak ada kesalahan generalisasi.

\section{Model Data Panel}

Penelitian ini berbentuk pengujian hipotesis (hipotesis testing) yang bertujuan untuk menguji seberapa besar pengaruh kepemilikan institusional dan dewan komisaris independen terhadap kinerja keuangan. Bentuk data yang digunakan dalam penelitian berupa data panel Yusra \& Hadya (2017) mengartikan, data panel merupakan gabungan antara data time series dan cross section. Pengelolaan data akan dilakukan dengan analisis data panel melalui salah satu Software pengolah data yaitu Eviews 8. Ada tiga jenis metode dalam pengujian yaitu:

Commont effect model dalam metode common effect model (CEM) menggabungkan seluruh data tanpa memperdulikan waktu dan tempat penelitian. diasumsikan bahwa perilaku data antar unit cross-section sama dalam berbagai kurun waktu. Dalam mengestimasi parameter common effect model dapat dilakukan dengan Ordinal Least Square (OLS) (Wulandari, 2017). Fixed effect model, salah satu cara untuk memperhatikan heterogenitas unit cross-section pada model regresi data panel adalah dengan mengizinkan nilai intersep yang berbeda-beda untuk setiap unit cross-section tetapi masih mengasumsikan slope konstan (Wulandari, 2017). Random effect model, estimasi random effect model ini diasumsikan bahwa efek individu bersifat random bagi seluruh unit cross-section (Wulandari, 2017).

\section{Uji Normalitas}

Indikator yang peneliti gunakan dalam uji normalitas adalah Jarque-Bera. Menurut Winarno (2017), Jarque-Bera adalah uji statistik untuk mengetahui apakah data berdistribusi secara normal atau tidak normal. Yusra \& Hadya (2017). Apabila hasil diperoleh hasil pengujian dengan nilai Probability lebih besar dari $\alpha$ (> 0.05). Hal ini menandakan bahwa data sudah terdistribusi normal. Begitupun sebaliknya jika hasilnya $<0,05$, disimpulkan model regresi yang digunakan adalah tidak normal atau dengan kata lain data yang digunakan sudah terdistribusi secara normal.

\section{Uji Lanjut}

Uji chow adalah pengujian untuk menentukan model apakah Common Effect (CE) ataukah Fixed effect (FE) yang paling tepat digunakan dalam mengestimasi 
data panel. Uji Hausman adalah pengujian statistik untuk memilih apakah model Fixed Effect (FE) atau Random Effect yang paling tepat digunakan.

\section{Analisis Regresi Data Panel}

Penelitian ini dilakukan untuk melihat pengaruh variabel independen terhadap variabel dependen. Analisis regresi data panel digunakan untuk melihat apakah hipotesis yang telah dibuat akan diterima atau ditolak. Tingkat signifikan yang digunakan adalah 5\%. Model statistik yang diestimasi merupakan model yang terbaik dan terbebas dari penyimpangan asumsi klasik (Yusra \& Hadya, 2017).

Keterangan:

$$
K_{\text {it }}=\alpha+\beta_{1} K I_{\text {it }}+\beta_{2} D K I_{\text {it }}+\varepsilon
$$

$\begin{array}{ll}\text { KK } & \text { : Kinerja Keuangan } \\ \alpha & : \text { Konstan } \\ \beta_{1,} \beta_{2}, & : \text { Koefisien Regresi } \\ \mathrm{KI}_{\text {it }} & : \text { Kepemilikan Institusional Perusahaan pada waktu t } \\ \text { DKI }_{\text {it }} & : \text { Dewan Komisaris Independen Perusahaan pada waktu t } \\ \varepsilon & : \text { Standar Errors }\end{array}$

\section{Uji Hipotesis}

Uji t

Uji hipotesis adalah jawaban atau dugaan terhadap rumusan masalah yang ada pada penelitian. Hipotesis berasal dari teori dan studi empiris yang telah dilakukan sebelumnya ataupun jurnal terkait dengan penelitian yang dilakukan (Lestari \& Priyadi, 2017) Uji t adalah pengujian secara statistic untuk mengetahui apakah variabel independen mempunyai pengaruh terhadap variabel dependen. Jika signifikan uji $\mathrm{t}>0,05$ maka Ho diterima dan Hi ditolak yang berarti ada pengaruh antara variabel bebas secara parsial terhadap variabel terikat. Jika nilai signifikan uji $\mathrm{t} \leq 0,05$ maka Ho ditolak dan Hi diterima yang berarti tidak ada pengaruh antara variabel bebas secara parsial terhadap variabel terikat.

HASIL DAN PEMBAHASAN

Uji Statistik Deskriptif Variabel

Tabel 1

Hasil Uji Statistik Deskriptif

\begin{tabular}{lccccc}
\hline & $\mathrm{N}$ & Minimum & Maksimum & Mean & $\begin{array}{c}\text { StandarDevia } \\
\text { si }\end{array}$ \\
\hline $\begin{array}{l}\text { Kinerja keuangan } \\
\begin{array}{l}\text { KK) } \\
\text { Kepemilikan }\end{array}\end{array}$ & 265 & 0.04 & 74.84 & 9.50 & 10.91 \\
$\begin{array}{l}\text { institusional (KI) } \\
\begin{array}{l}\text { Dewan komisaris } \\
\text { independen (DKI) }\end{array}\end{array}$ & 265 & 5.14 & 98.18 & 69.18 & 17.54 \\
\hline
\end{tabular}

Pada tabel diatas terlihat bahwa banyaknya data yang diteliti berjumlah 265 data. Penjelasan mengenai analisis statistik deskriptif dapat dijelaskan, kinerja keuangan terendah (minimum) ditempati oleh perusahaan PT Star Petrochem Tbk pada tahun 2014 dan 2015 yaitu sebesar 0.04. Sedangkan kinerja keuangan tertinggi (maximum) berada pada PT Duta Pertiwi Nusantara Tbk di tahun 2013 yaitu sebesar 
74.84. Hal ini dapat dijelaskan perusahaan tersebut memiliki tingkat ketergantungan yang tinggi terhadap laba bersih. Rata-rata (mean) dari nilai variabel kinerja keuangan adalah 9.50 dengan tingkat rata-rata penyimpangan (Std. deviation) sebesar 10.91. Hal ini diartikan bahwa data variabel kinerja keuangan memiliki sebaran data yang besar, dilihat dari nilai standar deviasi yang menunjukkan nilai lebih besar dari pada nilai mean-nya.

Kepemilikan institusional yang diukur menggunakan jumlah saham institusi dibagi dengan jumlah saham beredar bisa dilihat bahwa yang menunjukkan nilai terendah (minimum) ada pada PT Wismilak Inti Makmur Tbk 2017, sebesar 5.14. Nilai tertinggi (maximum) sebesar 98.18 yang berada pada PT HM Sampoerna Tbk pada tahun 2013 dan 2014. Hal ini dapat dijelaskan bahwa jumlah saham institusi memiliki jumlah yang besar dari jumlah saham beredar yang dimiliki oleh perusahaan tersebut. Rata-rata (mean) dari nilai variabel kepemilikan institusional adalah 69.18 dengan tingkat rata-rata penyimpangan (std. deviation) sebesar 17.54. Hal ini diartikan bahwa data variabel kepemilikan institusional memiliki sebaran data yang kecil, disebabkan nilai standar deviasi yang lebih kecil dari pada nilai mean.

Dewan komisaris independen yang diukur menggunakan jumlah komisaris independen dibandingkan dengan dewan komisaris bisa dilihat bahwa yang menunjukkan nilai terendah (minimum) sebesar 20.80 berada pada PT Kimia Farma Tbk pada tahun 2016, nilai tertinggi (maximum) sebesar 80.00 yang berada pada perusahaan PT Unilever Indonesia Tbk pada tahun 2013 sampai 2017. Perusahaan tersebut memiliki dewan komisaris yang banyak dapat meningkatkan kualitas fungsi pengawasan dalam perusahaan agar terciptanya Good Corporate Governance. Rata-rata (mean) dari nilai variabel dewan komisaris independen adalah 40.73 dengan tingkat rata-rata penyimpangan (std. deviation) sebesar 9.92. Hal ini diartikan bahwa data variabel dewan komisaris independen memiliki sebaran data yang kecil, disebabkan nilai standar deviasi yang lebih kecil dari pada mean-nya.

\section{Pemilihan Regresi Data Panel}

Estimasi model common effect model (CEM), fixed effect model (FEM), dan random effect model (REM) dilakukan untuk menganalisis model terbaik dalam data panel. Untuk mengestimasi model, persamaan regresi yang digunakan adalah sebagai berikut:

$$
\log K K \text { it }=\alpha+\beta 1 \log K \text { Iit }+\beta \text { DKIit }+ \text { eit }
$$

Tranformasi logaritma digunakan dalam persamaan ini untuk menentukan model yang terbaik. Hasil statistik yang diperoleh dalam estimasi model CEM, FEM, dan REM adalah sebagai berikut:

Tabel 2

Tabel Estimasi CEM, FEM, dan REM

\begin{tabular}{ccccccc}
\hline \multirow{2}{*}{ Variabel } & \multicolumn{2}{c}{ Common Effect } & \multicolumn{2}{c}{ Fixed Effect } & \multicolumn{2}{c}{ Random Effect } \\
\cline { 2 - 7 } & t-statistik & prob & t-statistik & prob & t-statistik & prob \\
\hline KI & 2.428506 & 0.0158 & 1.744293 & 0.0826 & 2.053115 & 0.0411 \\
DKI & 1.134937 & 0.2574 & 1.575709 & 0.1166 & 1.610191 & 0.1086 \\
\hline
\end{tabular}

Tabel 2 menjelaskan bahwa setiap model memiliki nilai signifikansi yang berbeda. Untuk menentukan model yang terbaik dari ketiga model tersebut di 
lakukan uji lanjut, hausmant test dipilih sebagai uji lanjut untuk menentukan model terbaik antara fixed effect model dengan random effect model.

\section{Uji Normalitas}

Terpilihnya random effect model (REM) sebagai model terbaik dalam regresi data panel, maka pengujian asumsi klasik sangat relevan untuk dilakukan. Pengujian asumsi klasik yang akan dilakukan hanya uji normalitas saja, uji multikolinearitas dan uji heteroskedastisitas tidak dilakukan karena telah diwakili oleh estimasi model pada regresi data panel.

Tabel 3

Uji Normalitas

\begin{tabular}{lc}
\hline Jarque-Bera & $\mathbf{5 . 0 4 9 5 2 3}$ \\
\hline Probability & $\mathbf{0 . 0 8 0 0 7 7}$ \\
\hline
\end{tabular}

Dilihat dari table 3 diatas dapat dillihat nilai probability lebih besar dari alpha $(0.080077>0.05)$. Hal ini menandakan bahwa data sudah terdistribusi normal.

Tabel 4

Uji Hausman

\begin{tabular}{lcrc}
\hline Test Summary & Chi-Sq.Statistic & Chi-Sq. d.f. & Prob. \\
\hline Cross-section random & 0.074778 & 2 & 0.9633
\end{tabular}

Hausmant test bertujuan untuk menentukan model terbaik antara fixed effect model dan random effect model. Tabel 3 menunjukkan bahwa nilai prob. pada Cross-section random lebih besar dari alpha $(\alpha)(0.9633>0.05)$. Dapat disimpulkan bahwa model yang cocok digunakan dalam regresi data panel adalah Random Effect Model (REM).

\section{Analisis Regresi Data Panel}

Penelitian ini bertujuan untuk melihat pengaruh independent variable terhadap dependent variable. Untuk melihat apakah hipotesis diterima atau ditolak digunakan analisis regresi data panel. Tingkat signifikansi yang digunakan adalah 5\%. Model statistik yang diestimasi adalah model terbaik dan terbebas dari gejala asumsi klasik. Hasil pengujian dapat dilihat pada Tabel berikut:

Tabel 5

Hasil Estimasi Regresi Data Panel

\begin{tabular}{ccccc}
\hline Variable & Coefficient & Std. Error & t-Statistic & Prob. \\
\hline C & -1.410210 & 1.278186 & -1.103290 & 0.2709 \\
KI & 0.434883 & 0.211816 & 2.053115 & 0.0411 \\
DKI & 0.412279 & 0.256044 & 1.610191 & 0.1086 \\
\hline
\end{tabular}

Persamaan Regresi Data Panel Random Effect Model adalah sebagai berikut: 


$$
\mathrm{KK}_{\mathrm{it}}=-1.4102+0.4348 \mathrm{Klit}+0.4122 \mathrm{DKI} \text { it }
$$

Dari model persamaan regresi diatas, dapat diinterpretasikan sebagai berikut:

1. Konstanta bernilai -1.410210 Ini menjelaskan bahwa jika diasumsikan variabel kepemilikan institusional bernilai 0 (tidak ada) maka kinerja keuangan bernilai konstan sebesar nilai -1.410210 .

2. Koefisien regresi kepemilikan institusional bernilai 0.434883 . Artinya setiap peningkatan variabel kepemilikan institusional sebanyak 1 satuan, berarti akan meningkatkan variabel kinerja keuangan perusahaan sebanyak 0.434883 serta variabel lain dianggap konstan.

3. Koefisien regresi dewan komisaris independen bernilai 0.412279. Artinya setiap peningkatan variabel dewan komisaris independen sebanyak 1 satuan, berarti akan meningkatkan variabel kinerja keuangan perusahaan sebanyak 0.412279 serta variabel lain dianggap konstan.

\section{Hasil Pengujian Hipotesis (Uji t)}

Pengujian ini bertujuan untuk mengetahui hubungan signifikan dari variabel kepemilikan institusional, variabel dewan komisaris independen ke variabel kinerja keuangan. Uji statistik T menunjukkan seberapa jauh pengaruh satu variabel independen secara individual dalam menerangkan variabel dependen.

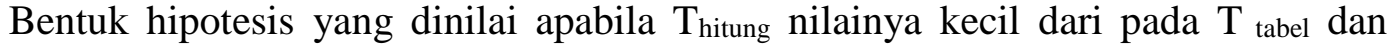
probability bernilai lebih besar dari alpha (0.05), maka Hipotesis 0 akan ditolak.

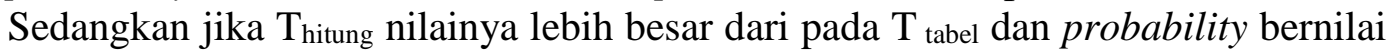
lebih kecil dari alpha (0.05), maka hipotesis akan diterima. ilai $\mathrm{t}$ hitung untuk variabel kepemilikan institusional diproksikan dengan KI senilai 2.053115, nilai ini lebih besar dari t tabel (1.969025). Nilai prob. kepemilikan institusional senilai 0.0411 , nilai ini lebih kecil dari pada 0,05. Dapat diartikan bahwa hipotesis pertama (H1) diterima, hasil ini membuktikan adanya pengaruh yang signifikan antara variabel kepemilikan institusional terhadap kinerja keuangan perusahaan.

Nilai t hitung untuk variabel dewan komisaris independen diproksikan dengan DKI senilai 1.610191. Nilai ini lebih kecil dari pada t table (1.969025). Nilai prob. dewan komisaris independen senilai 0.1086, nilai ini lebih besar dari pada alpha $(0,05)$. Dapat diartikan bahwa hipotesis kedua ditolak. Hasil ini sekaligus membuktikan tidak ada pengaruh yang signifikan antara variabel dewan komisaris independen terhjadap kinerja keuangan perusahaan.

\section{PEMBAHASAN}

\section{Pengaruh Kepemilikan Institusional Terhadap Kinerja Keuangan Perusahaan}

Penelitian yang dilakukan terhadap 265 data observasi dari data yang diperoleh dari perusahaan di Bursa Efek Indonesia (BEI) selama periode 2013 2017. Data tersebut kemudian diseleksi dengan menggunakan beberapa kriteria yang telah ditetapkan. Dari hasil estimasi dengan menggunakan program Eviews 8 dapat disimpulkan bahwa kepemilikan institusional sebagai $\mathrm{H} 1$ berpengaruh berpengaruh positif dan signifikan terhadap kinerja keuangan perusahaan.

Dapat ditunjukkan bahwa semakin tinggi kepemilikan institusional maka semakin kuat kontrol terhadap perusahaan, kinerja atau nilai perusahaan akan naik apabila pemilik perusahaan bisa mengendalikan perilaku manajemen agar bertindak sesuai dengan tujuan perusahaan. 
Hasil ini sejalan dan mendukung penelitian yang dilakukan oleh (Candradewi, Bagus \& Sedana, 2016) dan (Widyati, 2013). Artinya, apabila proporsi kepemilikan institusional yang besar dapat meningkatkan usaha pengawasan oleh pihak institusi sehingga dapat menghalangi perilaku oportunistik manajer dan dapat membantu pengambilan keputusan perusahaan, sehingga dapat meningkatkan kinerja keuangan perusahaan yang diukur dengan ROA. Adanya investor institusional dalam perusahaan dapat membantu mengurangi masalah keagenan yang terjadi, yaitu masalah yang timbul antara pihak manajemen dengan pihak pemegang saham.

\section{Pengaruh Dewan Komisaris Independen Terhadap Kinerja Keuangan Perusahaan}

Variabel dewan komisaris independen merupakan variabel bebas kedua yang di estimasi untuk melihat pengaruhnya terhadap kinerja keuangan perusahaan. Hasil penelitian menunjukkan dewan komisaris independen tidak menunjukkan adanya pengaruh yang signifikan, dapat disimpulkan bahwa $\mathrm{H} 2$ ditolak dan tidak dapat dijelaskan pengaruhnya terhadap kinerja keuangan perusahaan.

Dewan komisaris independen merupakan anggota komisaris yang tidak terafiliasi dengan manajemen, anggota komisaris lainnya dan pemegang saham. Adanya dewan komisaris independen, maka kepentingan pemegang saham, baik mayoritas maupun minoritas tidak diabaikan karena komisaris independen lebih bersikap netral terhadap keputusan yang dibuat oleh manajer.

Hasil ini tidak sejalan dan tidak mendukung penelitian yang dilakukan oleh (Noviawan \& Septiani 2013), dan (Fadillah,n.d) yang menemukan adanya pengaruh negative dan signifikan dewan komisaris independen terhadap kinerja keuangan perusahaan. Hasil penelitian menunjukkan dewan komisaris independen tidak menunjukkan adanya pengaruh yang signifikan, dapat disimpulkan bahwa $\mathrm{H} 2$ ditolak.

Pengujian yang dilakukan terhadap variabel dewan komisaris independen dalam pengaruhnya terhadap kinerja keuangan perusahaan, menemukan adanya pengaruh positif dan tidak signifikan dewan komisaris independen terhadap kinerja keuangan perusahaan. Hasil ini di dukung oleh penelitian yang dilakukan oleh (Candradewi, Bagus \& Sedana, 2016). Pengaruh dewan komisaris independen tidak signifikan dapat disebabkan karena kecilnya persentase keberadaan dewan komisaris independen dalam meningkatkan Return On Asset perusahaan. Dewan Komisaris dengan anggota independen yang lebih banyak akan cenderung memberikan pengawasan yang lebih besar terhadap manajemen perusahaan dalam meningkatkan kinerja perusahaan (ROA).

\section{SIMPULAN}

Berdasarkan hasil penelitian dan pembahasan mengenai pengaruh kepemilikan institusional dan dewan komisaris independen terhadap kinerja keuangan perusahaan manufaktur yang terdaftar di BEI periode tahun 2013-2017 dengan menggunakan teknik analisis regresi data panel.

Kepemilikan Institusional menghasilkan hipotesis yang berpengaruh positif dan signifikan terhadap kinerja keuangan. Yang artinyaapabila proporsi 
kepemilikan institusional yang besar dapat meningkatkan usaha pengawasan oleh pihak institusi sehingga dapat menghalangi perilaku oportunistik manajer dan dapat membantu pengambilan keputusan perusahaan, sehingga dapat meningkatkan kinerja keuangan perusahaan. Hipotesis pertama diterima.

Dewan komisaris independen memberikan hipotesis yang positif dan tidak signifikan terhadap kinerja keuangan. Yang artinya, dewan komisaris independen tidak signifikan dapat disebabkan karena kecilnya persentase keberadaan dewan komisaris independen dalam meningkatkan Return On Asset perusahaan. Hipotesis kedua ditolak.

Ada beberapa keterbatasan yang ditemukan dalam penelitian ini, diantaranya adalah jumlah observasi yang digunakan relatif sedikit, disebabkan karena banyak ditemukan data-data yang bersifat ekstrem dalam proses pengumpulan data. Keterbatasan lain adalah faktor-faktor yang digunakan hanya terbatas pada dua faktor saja, yaitu kepemilikan institusional dan dewan komisaris independen. Dengan keterbatasan tersebut, penelitian yang dilakukan belum memberikan gambaran yang maksimal. Untuk peneliti selanjutnya dapat menambah alat ukur yang berbeda seperti : Return on Equity (ROE), Return On Investment (ROI), Net Profit margin (NPM). Dan untuk peneliti selanjutnya setelah penelitian ini dapat melakukan penelitian dengan menambahkan variabel-variabel GCG yang lain seperti menambahkan variabel komite audit, kepemilikan manajerial, dewan direksi.

\section{UCAPAN TERIMA KASIH}

Peneliti mengucapkan terima kasih kepada pihak-pihak yang telah memberikan dukungan dan dorongan dalam melakukan penelitian ini. Penghargaan dan ucapan terima kasih kepada Bursa Efek Indonesia yang telah menyediakan akses kedalam laporan keuangan tahunan (Annual Report dan Summary) perusahaan yang terdaftar di BEI. Sehingga memudahkan peneliti untuk mengumpulkan data sesuai dengan data yang peneliti butuhkan.

Terima kasih juga penulis ucapkan kepada Ketua Sekolah Tinggi Ilmu "KBP", Ketua Program Studi Manajemen, Dosen Pembimbing serta dosen dan karyawan Sekolah Tinggi Ilmu "KBP" yang telah memberikan support, mengizinkan kepada penulis untuk melakukan penelitian dan penulisan jurnal ini.

\section{DAFTAR PUSTAKA}

Andriza, R., \& Yusra, I. (2019). Pengaruh kepemilikan manajerial dan kebijakan deviden terhadap kemakmuran Investor dan nilai perusahaan yang tercatat pada indeks LQ45. INA-Rxiv.

Angraini, I., \& Yusra, I. (2019). Pendekatan data panel terhadap return saham: studi empiris pada perusahaan LQ45. INA-Rxiv.

Candradewi, Bagus, \& Sedana. (2016). ISSN : 2302-8912 Pengaruh Kepemilikan Manajerial , Kepemilikan Institusional Dan Dewan Komisaris Independen Terhadap Return On Asset Fakultas Ekonomi Dan Bisnis Universitas Udayana ( Unud ), Bali , Indonesia Menghadapi persaingan bisnis yang kompetitif ,. EJurnal Manajemen Unud, 5(5), 3163-3190. 
Dewi, A. S., Sari, D., \& Abaharis, H. (2018). Pengaruh Karakteristik Dewan Komisaris Terhadap Kinerja Perusahaan Manufaktur Di Bursa Efek Indonesia. Jurnal Benefita, 3(3), 445-454.

Dewi, A. S., Zusmawati, \& Lova, N. H. (2018). Analisis Kinerja Keuangan Dan Ukuran Perusahaan Terhadap Harga Saham Perusahaan Dalam Indeks LQ45 Di BEI Dengan Data Panel. Jurnal Pundi, 02(02), 119-134.

Erawati, L., \& Dewi, A. S. (2019). Peran Profitabilitas Sebagai Variabel Interverning Dan Pengaruh Struktur Modal Terhadap Nilai Perusahaan. INARxiv.

Fajri, I., \& Dewi, A. S. (2019). Analisis Likuiditas, Profitabilitas, dan Return Saham pada Perusahaan Manufaktur di Indonesia. INA-Rxiv.

Gusnita, E., \& Martha, L. (2019). Analisis Struktur Modal Dalam Memoderasi Pengaruh Kepemilikan Manajerial Dan Pertumbuhan Perusahaan Terhadap Nilai Perusahaan Di Indonesia. INA-Rxiv.

Hadya, R. (2014a). Analisis likuiditas, solvabilitas, nilai pasar dan return saham: studi empiris pada perusahaan sektor perbankan yang terdaftar di Bursa Efek Indonesia. Jurnal Riset Manajemen Dan Akuntansi, 3(1), 107-118.

Hadya, R. (2014b). Earning Surprise, Ketepatan Waktu Pengumuman Laporan Keuangan Dan Reaksi Pasar. Jurnal Riset Manajemen Dan Akuntansi, 1(2).

Hadya, R., Begawati, N., \& Yusra, I. (2017). Analisis Efektivitas Pengendalian Biaya, Perputaran Modal Kerja, dan Rentabilitas Ekonomi Menggunakan Regresi Data Panel. Jurnal Pundi, 01(03), 1-35.Harjito, A., \& Martono. (2011). Manajemen Keuangan. (Ekonisia, Ed.), Historia Social (edisi 2). yogyakarta. https://doi.org/10.1145/2505515.2507827

Hanafi, D., \& Yusra, I. (2019). Tangibility, liquidity, growth opportunity, dan leverage: studi pada perusahaan terdaftar di Bursa Efek Indonesia. INA-Rxiv, (2001).

Handayani, F., \& Martha, L. (2019). Hubungan Antara Profitabilitas Dengan Nilai Perusahaan Yang Dimoderasi Oleh Corporate Social Responsibility. INARxiv.

Harahap, R. L., \& Sari, L. F. (2019). Analisis Nilai Perusahaan Berdasakan Profitabilitas, Ukuran Perusahaan, Dan Struktur Modal Di Indonesia. INARxiv.

Hidayanti, E., \& Paramita, R. W. D. (2014). Pengaruh Good Corporate Governance Terhadap Praktik. Jurnal WIGA, 4(2), 1-16.

Kartin, Y. R., \& Dewi, A. S. (2019). Karakteristik Dewan Komisaris Dan Dampaknya Terhadap Kinerja Keuangan. INA-Rxiv. 
Kurniawan, A., \& Yusra, I. (2019). Apakah profitabilitas dan nilai buku berdampak terhadap return saham?: studi empiris pada perusahaan LQ45. INA-Rxiv.

Lestari, I. A., \& Priyadi, M. P. (2017). Pengaruh Rasio Keuangan Terhadap Kebijakan Dividen Dengan Good Corporate Governance Sebagai Variabel. Jurnal Ilmu Dan Riset Akuntansi, 6(September), 1-22.

Martha, L. (2018). Peranan Analisis Laporan Keuangan terhadap Pengambilan Keputusan Pemberian Kredit Pada PT. BPR LPN Sungai Rumbai Kabupaten Dharmasraya. INA-Rxiv.

Martha, L., Sogiroh, N. U., Magdalena, M., \& Susanti, F. (2018). Profitabilitas dan Kebijakan Dividen terhadap Nilai Perusahaan. Jurnal Benefita, 3(2), 227-238.

Mulfita, A., \& Yusra, I. (2019). Analisis regresi data panel terhadap likuiditas saham di Indonesia. INA-Rxiv.

Pricilia, S. (2017). Pengaruh Kepemilikan Institusional, Kepemilikan Manajerial, Komisaris Independen, dan Ukuran Dewan Komisaris terhadap Manajemen Laba Serta Implikasinya terhadap Kinerja Keuangan pada Perusahaan Manufaktur yang terdaftar di Bursa Efek Indonesia Periode 2012-2014. Ecojoin, XXII(02), 267-283.

Purnama, S., \& Mayliza, R. (2019). Nilai Perusahaan Di Lihat Dari Aspek Profitabilitas, Ukuran Perusahaan Dengan Struktur Modal Sebagai Variabel Intervening. INA-Rxiv.

Puspitasari, F., \& Ernawati, E. (2010). Pengaruh Mekanisme corporate Governance terhadap Kinerja Keuangan Badan Usaha. Jurnal Manajemen Teori Dan Terapan, 1999(2), 189-215.

Putra. (2017). Pengaruh Kelola Perusahaan Terhadap Kinerja Keuangan Perusahaan Sekolah Tinggi Ilmu Ekonomi Indonesia ( STIESIA ) Surabaya. Ilmu Dan Riset Akuntansi, 6(8), 1-17.

Putra, A. D., \& Yusra, I. (2019). Peran profitabilitas dalam memoderasi pengaruh free cash flow terhadap kebijakan dividen di Indonesia. INA-Rxiv.

Putra, B. P. D. (2015). Pengaruh dewan komisaris, proporsi komisaris independen, terhadap kinerja perusahaan. Jurnal Manajemen Teori Dan Terapan, (2), 7085 .

Putra, I., \& Yusra, I. (2019). Analisis likuiditas saham menggunakan regresi data panel. INA-Rxiv.

Qusibah, V. L., \& Yusra, I. (2019). Profitabilitas , dan Ukuran Perusahaan Sebagai Faktor Penentu Leverage Perusahaan Di Indonesia. Jurnal Pundi, 03(01), 1326. https://doi.org/10.31575/jp.v3i1.125

Saputra, J., \& Martha, L. (2019). Analisis Kinerja Keuangan Dan Nilai Perusahaan, 
Serta Pengaruhnya Terhadap Harga Saham. INA-Rxiv.

Sugiyono. (2017a). metode penelitian. In metode penelitian kuantitatif, kualitatif dan $R \& D$ (26th ed., p. 334). bandung: alfabeta.

Sugiyono. (2017b). Metode Penelitian Bisnis. In Metode Penelitian Bisnis. Bandung: Alfabeta.

Suhartono, \& Yusra, I. (2019). Analisis perbandingan kinerja keuangan bank konvensional dengan bank syariah yang terdaftar di BEI. INA-Rxiv, 1-9.

Wahyudi, R., \& Martha, L. (2019). Analisis Modal Intelektual Dan Kinerja Keuangan Dan Pengaruhnya Terhadap Nilai Perusahaan. INA-Rxiv.

Wahyuni, I., \& Mayliza, R. (2019). Peran Kebijakan Deviden Dalam Memediasi Pengaruh Profitabilitas Terhadap Nilai Perusahaan. INA-Rxiv.

Widyati, M. F. (2013). Pengaruh Dewan Direksi, Komisaris Indepeden, Komite Audit, Kepemilikan Manajerial dan Kepemilikan Institusional terhadap Kinerja Keuangan. Jurnal Ilmu Manajemen, 1(1), 234-249.

Winarno, W. W. (2017). Analisis Ekonometrika dan Statistika dengan Eviews. In Analisis Ekonometrika dan Statistika dengan Eviews (5th ed.). Yogyakarta: UPP STIM YPKN.

Wulandari, N. (2017). Analisis Faktor-Faktor yang Mempengaruhi Inflasi pada Kota Metropolitan di Indonesia dengan Menggunakan Analisis Data Panel, 3(2), 34-42.

Yusra, I., \& Hadya, R. (2017). Analisis Efektivitas Pengendalian Biaya, Perputaran Modal Kerja, Dan Rentabilitas Ekonomi Menggunakan Regresi Data Panel, 01(03), 1-35.

Yusra, I., Hadya, R., Begawati, N., \& Istiqomah, L. (2019). Panel data model estimation: the effect of managerial ownership, capital structure, and company size on corporate value Panel data model estimation : the effect of managerial ownership, capital structure, and company size on corporate value. Journal of Physics: Conference Series, 1175, 1-6. https://doi.org/10.1088/1742$6596 / 1175 / 1 / 012285$

Yusra, I., Hadya, R., \& Fatmasari, R. (2019). The Effect of Retained Earnings on Dividend Policy from the Perspective of Life Cycle. Advances in Social Science, Education and Humanities Research, 203(Iclick 2018), 216-220.

Yusuf, D., \& Yusra, I. (2019). Faktor-faktor yang mempengaruhi struktur modal perusahaan. INA-Rxiv.

Zahra, F. N. (2016). Pengaruh Komisaris Independen, Ukuran Dewan Komisaris, Dan Frekuensi Rapat Dewan Komisaris Terhadap Profitabilitas. E-Proceeding of Management, 3(3), 3324-3331. 
